\title{
The Effect of Addition of Used Styrofoam on the Characteristics of Asphalt Physical Properties
}

\author{
Diana Alemin Barus ${ }^{1 *}$ and Alesia Lorenzza Sinaga ${ }^{2}$ \\ ${ }^{1,2}$ Department of Physics, Faculty of Mathematics and Natural Science, Universitas Sumatera Utara, \\ Medan 20155, Indonesia
}

\begin{abstract}
Styrofoam had many purposes, especially for the safety of electronic objects, because it is light, durable and strong. The volume of styrofoam is enormous, reaching $30 \%$ of total waste in the world. Therefore, it causes problems if disposed of and it will become a very inconvenient waste and it can undermine the environment. This study aims to determine the effect of adding former styrofoam waste to asphalt on the characteristics of the 60/70 pen asphalt. The sample was made by melting the Styrofoam with Xylene then putting it in heated asphalt and then stirring it evenly. Next, Styrofoam enters the material into the sample container and then is refrigerated outside for 1 hour. After that, the sample is immersed in water for 3 hours. The sample meets the asphalt requirements test for each sample including penetration test, softening point, flash point, burning point, density, and ductility. This shows that the higher the concentration, the addition of styrofoam mixed with asphalt resulted in conversion and increased performance of the mixture. While at density, it appears that the addition of Styrofoam results in a lower density value.
\end{abstract}

Keyword: styrofoam, asphalt, physical properties.

Received 14 July 2020 | Revised [28 July 2020] | Accepted [27 August 2020]

\section{Introduction}

Styrofoam has very light, rigid, translucent, and inexpensive properties. This makes styrofoam has the potential to be a mixing material to make modified asphalt. The use of modified asphalt using styrofoam mixture material still has to go through several stages of testing and evaluation [1]. Testing and evaluation aims to determine the strength of modified asphalt when applied as a highway manufacturing material [2]. The use of asphalt pen 60/70 on pavement in the long term is not good enough to withstand heavy loads (overloading), so it is necessary to add additives to make asphalt more durable [3].

Styrofoam is divided into 2 namely Foamed Styrofoam (FS) and Expanded Styrofoam (EPS), also known as Polystyrene foam, which is commonly known as styrofoam [4]. In some countries, styrofoam has been applied as an additional material on asphalt. In Baghdad, Iraq, styrofoam has been used on several roads and can lower cracks and rutting, reduce aging,

\footnotetext{
*Corresponding author at: Jalan Biolteknologi no.1 Medan, 20155, Indonesia

E-mail address: dianabarus@usu.ac.id
} 
increase skid resistance [5]. Efforts to improve the quality of the hard layer should still take into account the funding conditions. Nowadays it has been widely used a variety of added materials to improve the quality of asphalt mixtures, among others by adding polymers [6]. Styrofoam can reduce vulnerability to temperature fluctuations, reducing maintenance costs as it improves durability and pavement performance. In addition, its use in asphalt mixture can reduce styrofoam waste by $40-88 \%$ [7].

Roads as land transportation infrastructure is very important. Road as one form of land transportation system that serves to connect one area with another area [8]. Indonesia's road network has been traversed by traffic with increasing load characteristics, high traffic volume and not comparable to available capacity, as well as increasing double pressure [9-10]. Road is one of the factors that influence the development of development in Indonesia. The quality of the road is comparable to the level of smoothness of road transportation. One of the factors that affect the quality of the highway is the material used in road construction [11].

Materials used in road construction include asphalt. Mixing with other materials makes the use of asphalt reduced. There are several materials that can be used as asphalt mixing material, one of which is styrofoam. Styrofoam has very light, rigid, translucent, and inexpensive properties. This makes styrofoam has the potential to be a mixing material used to make modified asphalt [12]. Styrofoam is used based on considerable use in everyday life but is little utilized. The use of modified asphalt using styrofoam mixture material still has to go through several stages of testing and evaluation. Testing and evaluation aims to find out the strength of asphalt modifications when applied as road construction materials. Assessment of Handling Plastic Deformation and Cracks due to Traffic Load has been researched by the Research and Development Agency of the Department of Public Works [13]. The use of added material type on asphalt material depends on the objectives to be achieved, namely improving asphalt chemistry with additional materials such as arbocell, roadcel-50 [14]. Styrofoam Can also serve as an adhesive if mixed with gasoline.

In this study, tried using Styrofoam material mixed with asphalt material to see changes in the physical properties of asphalt [15]. The results of this study will provide preliminary information about the characteristics of asphalt concrete mixture that can be improved by the addition of Styrofoam into the asphalt concrete mixture [16-17].

\section{Methods}

This research was conducted in The Construction Materials Laboratory of Bina Marga and Construction Development of North Sumatra Province. 


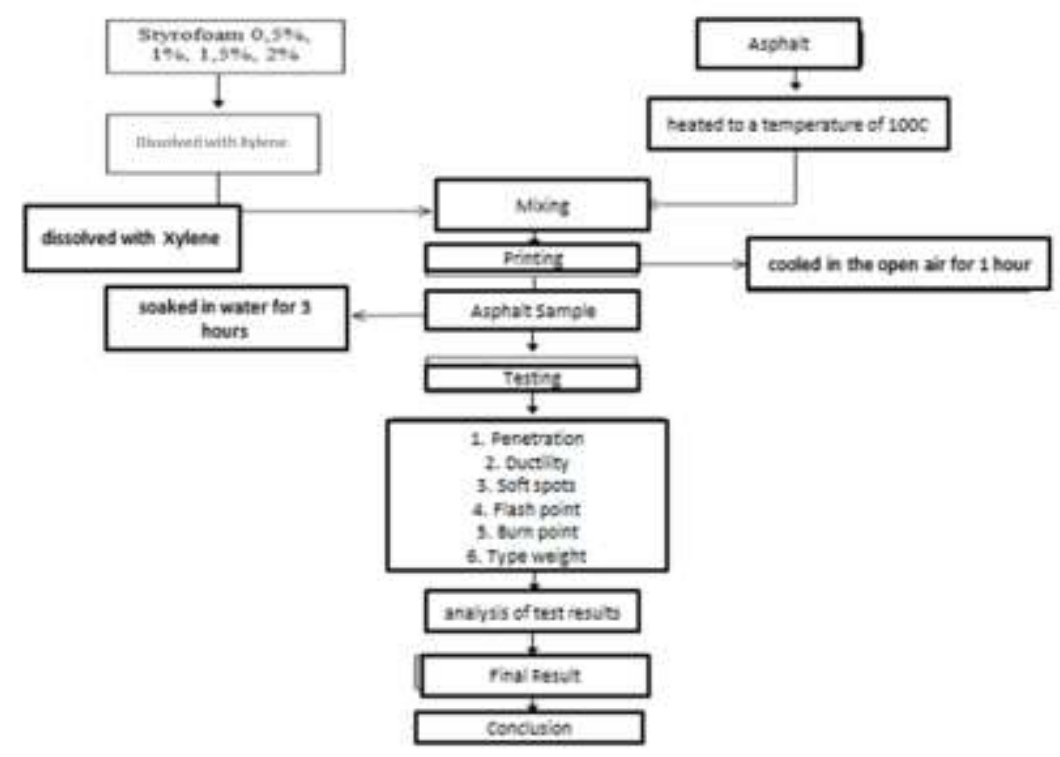

Figure 1. Research Flowchart

\section{Result and Discussion}

\subsection{Penetration Test Results}

Table 1. 60/70 Pen asphalt penetration test results with Styrofoam

\begin{tabular}{cccc}
\hline \multirow{2}{*}{ Sample } & \multicolumn{2}{c}{ Material Composition } & $\begin{array}{c}\text { Penetration Results } \\
(\mathrm{mm})\end{array}$ \\
\cline { 2 - 3 } & Asphalt $(\mathrm{g})$ & Styrofoam $(\%)$ & 60 \\
A1 & 800 & 0 & 65 \\
A2 & 800 & 0.5 & 69 \\
A3 & 800 & 1 & 71 \\
A4 & 800 & 1.5 & 73 \\
A5 & 800 & 2 & \\
\hline
\end{tabular}

Table 1 Shows that the higher the concentration of Styrofoam addition mixed on asphalt resulting in a change in asphalt penetration value.

\subsection{Soft Spot Test Results}

Table 2. Test result of soft spot asphalt pen 60/70 with Styrofoam

\begin{tabular}{ccccc}
\hline Sample & \multicolumn{2}{c}{ Material Composition } & Time $(\mathrm{s})$ & $\begin{array}{c}\text { Soft Spot Test } \\
\text { Results }\left({ }^{\circ} \mathrm{C}\right)\end{array}$ \\
\hline Asphalt $(\mathrm{g})$ & Styrofoam $(\%)$ & 0 & 10.13 & 48 \\
L2 & 800 & 0.5 & 12.45 & 49 \\
L3 & 800 & 1 & 16.50 & 50 \\
L4 & 800 & 1.5 & 15.26 & 51 \\
L5 & 800 & 2 & 14.17 & 53 \\
\hline
\end{tabular}

Table 2 shows that the value of asphalt soft spots is $48^{\circ} \mathrm{C}$. The addition of Styrofoam by $0.5 \%$ to $2 \%$ has an impact on increasing the value of soft spots to $49^{\circ} \mathrm{C}$ to $53^{\circ} \mathrm{C}$. 
3.3 Test Results of Flashpoints and Burn Points

Table 3. 60/70 asphalt pen test results with styrofoam

\begin{tabular}{ccccc}
\hline \multirow{2}{*}{ Sample } & \multicolumn{2}{c}{ Material Composition } & \multicolumn{2}{c}{ Results } \\
& Asphalt $(\mathrm{g})$ & Styrofoam $(\%)$ & Flash Points $\left({ }^{\circ} \mathrm{C}\right)$ & Burn Points $\left({ }^{\circ} \mathrm{C}\right)$ \\
\hline N1 & 800 & 0 & 200 & 250 \\
N2 & 800 & 0.5 & 255 & 285 \\
N3 & 800 & 1 & 260 & 290 \\
N4 & 800 & 1.5 & 266 & 295 \\
N5 & 800 & 2 & 268 & 300 \\
\hline
\end{tabular}

Table 3 shows that the point value of Asphalt flame is $200^{\circ} \mathrm{C}$. The addition of Styrofoam by $0.5 \%$ to $2 \%$ has an impact on the increase in the value of the point to $255^{\circ} \mathrm{C}$ to $266^{\circ} \mathrm{C}$. Then at the asphalt burn point value is $250^{\circ} \mathrm{C}$. The addition of Styrofoam by $0.5 \%$ to $2 \%$ has an impact on the increase in the value of the point to $285^{\circ} \mathrm{C}$ to $300^{\circ} \mathrm{C}$.

\subsection{Ductility Test Results}

Table 4. 60/70 asphalt pen ductility test results with Styrofoam

\begin{tabular}{cccc}
\hline \multirow{2}{*}{ Sample } & \multicolumn{2}{c}{ Material Composition } & Ductility Results $(\mathrm{cm})$ \\
\hline D1 & 800 & Styrofoam $(\%)$ & 100 \\
D2 & 800 & 0.5 & 110 \\
D3 & 800 & 1 & 118 \\
D4 & 800 & 1.5 & 126 \\
D5 & 800 & 2 & 130 \\
\hline
\end{tabular}

Table 4 shows that the length of the test trough in this study was $152 \mathrm{~cm}$. The minimum required ductile value is $100 \mathrm{~cm}$. The following results of ductility testing addition of Styrofoam were $110 \mathrm{~cm}$ to $130 \mathrm{~cm}$.

\subsection{Weight Type Test Results}

Table 5. Test result of asphalt pen type weight $60 / 70$ with styrofoam

\begin{tabular}{cccc}
\hline \multirow{2}{*}{ Sample } & \multicolumn{2}{c}{ Material Composition } & Results $(\mathrm{g} / \mathrm{mm})$ \\
\hline J1 & Aspal $(\mathrm{g})$ & Styrofoam $(\%)$ & 1 \\
J2 & 800 & 0 & 1.0855 \\
J3 & 800 & 0.5 & 1.0189 \\
J4 & 800 & 1 & 0.9861 \\
J5 & 800 & 1.5 & 0.9810 \\
\hline
\end{tabular}

Indicates that the Mass Value of asphalt type is the highest density, which is $1 \mathrm{~g} / \mathrm{ml}$. It appears that the addition of Styrofoam resulted in a lower density value [2].

\section{Conclusion}

The addition of styrofoam into the asphalt is likely to increase the penetration value of asphalt which means the asphalt becomes softer. The test results of asphalt physical properties are as 
follows: penetration value of $60 \mathrm{~mm}$ to $73 \mathrm{~mm}$. Soft spots at mixed levels of $48^{\circ} \mathrm{C}$ to $53^{\circ} \mathrm{C}$. The flash point is $200^{\circ} \mathrm{C}$ to $268^{\circ} \mathrm{C}$. The burn points were $250^{\circ} \mathrm{C}$ to $300^{\circ} \mathrm{C}$. As the temperature increases, the faster it rises and burns. Ductility test values were $100 \mathrm{~cm}$ to $130 \mathrm{~cm}$. The density test value of $1 \mathrm{~g} / \mathrm{ml}$ to $0.9810 \mathrm{~g} / \mathrm{ml}$ decreased against the addition of styrofoam levels. This research is the basis for looking at the ability to mix asphalt with polymer materials where in this study is styrofoam. The results showed that the more styrofoam percentage on asphalt will further improve the performance of the mixture with the use of styrofoam.

\section{REFERENCES}

[1] G. A. Jacobson and S. McLean, "Biological Monitoring of Low Level Occupational Xylene Exposure and the Role of Recent Exposure," Ann Occup Hyg, vol. 47, no. 4, pp. 331-336, 2003.

[2] M. B. Baker, R. Abendeh, Z. Abu-Salem and T. Khedaywi, "Production of Sustainable Asphalt Mixes Using Recycled Polystyrene," International Journal of Applied Environmental Sciences, vol. 11, no. 1, pp. 183-192, 2016.

[3] Soehartono, Teknologi Aspal dan Penggunaan dalam Konstruksi Perkerasan Jalan, Yogyakarta: Penerbit Andi, 2015.

[4] S. Sukirman, Beton Aspal Campuran Panas, Jakarta: Granit, 2003.

[5] I. S. J. Al-Haydari and G. G. Masued, "Benefit of Using Expanded Polystyrene Packing Material to Improve Pavement Mixture Properties," Applied Research Journal, vol. 3, no. 11, pp. 332-342, 2017.

[6] British Standard (BS), Bituminous mixtures - Test methods for hot mix asphalt, Part 25: Cyclic compression test, BS EN 12697-25, 2005.

[7] S. M. Saleh, R. Anggraini and H. Aquina, "Karakteristik Campuran Aspal Porus dengan Substitusi Styrofoam pada Aspal Penetrasi 60/70," Jurnal Teknik Sipil: Jurnal Teoritis dan Terapan Bidang Rekayasa Sipil, vol. 21, no. 3, pp.241-250, 2014.

[8] R. Permana and I. Aschuri, "Studi Sifat-Sifat Reologi Aspal yang Dimodifikasi Limbah Tas Plastik," in Simposium XII FSTPT. Universitas Kristen Petra Surabaya, 16-17 Oktober 2009, Surabaya, pp. 1-10, 2009.

[9] W. Kunhua, F. Chuming, L. Tao, Y. Yanmei, Y. Xin, Z. Xiaoming, G. Xuezhong and L. Xun, "A Novel Non-Toxic Xylene Substitute (SBO) for Histology," Afr. J. Tradit. Complement Altern. Med., vol. 9, no. 1, pp. 43-49, 2011.

[10] S. Abinaya, M. Clement and S. Shanmugam, "An Experimental Study on the Properties of Extruded Polystyrene Waste Polymer Modified Bitumen for Flexible Pavement," International Research Journal of Engineering and Technology (IRJET), vol. 3, no. 6, pp. 2468-2472, 2016.

[11] H. Aquina, "Pengaruh Substitusi Styrofoam ke dalam Aspal Penetrasi 60/70 terhadap Karakteristik Campuran Aspal Porus," M.S. thesis, Universitas Syiah Kuala, D. I. Aceh, 2014.

[12] A. Listiani, E. Sembiring and H. Rahman, "Evaluation of Expanded Polystyrene (EPS) Plastic Waste Utilization as an Asphalt Substitution Material in Asphalt Concrete Wearing Course Layer," in $5^{\text {th }}$ Environmental Technology and Management Conference (ETMC) 2015, Bandung Indonesia, 2015.

[13] J. F. Soandrijanie L, "Pengaruh Styrofoam terhadap Stabilitas dan Nilai Marshall Beton Aspal," in Seminar Nasional-1 BMPTTSSI - KoNTekS 5, USU, Medan- 14 Oktober 2011, Medan, Indonesia, 2011.

[14] S. Diansari, "Aspal Modifikasi dengan Penambahan Plastik Low Linear Density Polyethylene (LLDPE) Ditinjau Dari Karakteristik Marshall dan Uji Penetrasi Pada Lapisan Aspal Beton (AC-BC)," Undergraduate thesis, Universitas Lampung, Bandar 
Lampung, 2016.

[15] The Asphalt Institute, Superpave Performance Graded Asphalt Binder Specification and Testing, Superpave Series No.1, Third Edition, USA: Asphalt Insitute, 2003.

[16] Y. L. Sitanggang, "Pengaruh Penggunaan Styrofoam sebagai Bahan Tambah terhadap Karakteristik Beton Aspal," Undergraduate thesis, Universitas Atma Jaya Yogyakarta, Yogyakarta, 2010.

[17] Mashuri, "Karakteristik Aspal Sebagai Bahan Pengikat yang Ditambahkan Styrofoam," Jurnal SMARTek, vol. 8, no. 1, pp. 1-12, 2010. 